\title{
Research on the Industrialization Inheritance of Intangible Cultural Heritage in Guizhou: A Case Study of Ethnic Songs, Dances and Operas
}

\author{
Wen-jing FAN* \\ School of Economics and Management \\ Beijing Institute of Graphic Communication \\ Beijing, China
}

\begin{abstract}
Guizhou Province has a large number of ethnic songs, dances and operas, which are precious intangible cultural heritage wealth. The singing and dancing art, which was produced and spread in the traditional farming society, is facing the situation of being lost because of its low practicability in today's era. Through field investigation, interviews and case studies, this paper summarized the problems existing in the inheritance of ethnic songs, dances and operas in Guizhou. In order to promote the inheritance of intangible cultural heritage, the paper put forward suggestions on the inheritance of ethnic songs, dances and operas from the perspective of developing cultural industries. The laborers, labor materials, and labor objects of cultural production are the three elements to promote the development of cultural productivity. Based on the above theory, the paper gave specific suggestions on how to improve the cultural productivity and the industrialization degree of ethnic songs, dances and operas.
\end{abstract}

Keywords-Intangible Cultural Heritage; Ethnic Songs, Dances and Operas; Industrialization; Inheritance; Guizhou

\section{RESEARCH BACKGROUND}

In 2017, general secretary Xi Jinping stressed that "creative transformation and innovative development of Chinese traditional culture" is a scientific guidance for the better transmission and development of traditional culture in the present era. At the "40th Anniversary Session of Reform and Opening up" in 2018, Xi Jinping emphasized again: "promoting the creative transformation and innovative development of Chinese traditional culture, carrying forward revolutionary culture and developing advanced culture." This guided us to use China's excellent traditional culture scientifically, develop cultural industry, prosper cultural undertakings and meet the people's growing needs for a better life. From 2009 to 2018, the proportion of added value of China's culture and related industries in GDP increased year by year, from $2.54 \%$ in 2009 to $4.30 \%$ in 2018 . According to the general standard that the pillar industry accounts for $5 \%$ of GDP, the cultural industry will soon become the pillar industry of the national economy. With the development of technologies such as the Internet, virtual reality, and block chain, new formats and new models of cultural industry are constantly emerging and developing rapidly. They are increasingly

Sponsors : Beijing Cultural Industry and Publishing Media Research Base Project (04190119001/028); Youth project of Beijing Social Science Fund(18GLC050). becoming new growth points for cultural industry and have spawned new creative industries and creative economies. Intangible cultural heritage comes from the way of production and life of human beings. It exists on the basis of human beings and embodies people's aesthetics, beliefs, values and creativity. Intangible cultural heritage is a "living" culture. The ethnic songs, dances and operas, which integrate images, sounds and techniques, are more appealing "living" arts. Under the background of the development of cultural industry, how to creatively transform and develop national cultural resources such as ethnic songs, dances and operas, and how to develop life vitality relying on new technology are not only the needs of intangible cultural heritage protection but also the needs of people's spiritual and cultural life.

\section{THE BASIS OF ETHNIC SONGS, DANCES AND OPERAS RESOURCES IN GUIZHOU}

Guizhou has a long history of many ethnic groups, and the characteristics of various ethnic groups living together form a colorful ethnic culture. Singing and dancing is the most basic entertainment and social activity for ethnic minorities in Guizhou. Rest and work, walking and driving, love and marriage, and funeral ancestors are all inseparable from singing and dancing. Singing and dancing is a way for people to express their feelings and convey their beliefs, which is integrated into every detail of people's life. There are countless wonderful ethnic songs, dances and operas in the minority areas of Southeast Guizhou, Northwest Guizhou, Northeast Guizhou and South Guizhou. The Grand Song of Dong Minority, Miao's Flying Song, Yi's Bell Dance, Buyi's Eight Notes Sitting Singing, Nuo Opera and so on fully show the rich spiritual world of Guizhou people. As of 2019, 85 items (140 sites) of intangible cultural heritage in Guizhou have been included in the National Intangible Heritage List, and 628 items (1026 sites) of intangible cultural heritage have been included in the Provincial Intangible Heritage List. There are 23 national intangible cultural heritages (see Table I), accounting for $27 \%$ of the total number of intangible cultural heritages in Guizhou. This shows the important position of ethnic songs, dances and operas in the production and life of Guizhou people. 
TABLE I.

National Intangible Cultural Heritage of Ethnic Songs, Dances and Operas in Guizhou

\begin{tabular}{|c|c|c|}
\hline Category & Sites & Batch \\
\hline \multirow{3}{*}{$\begin{array}{l}\text { Traditional } \\
\text { Music }\end{array}$} & Grand Song of Dong Minority in Liping County, Dong's Pipa Song in Rongiiang and Liping County & First \\
\hline & $\begin{array}{l}\text { Miao's folk song in Leishan County (Miao's Flying Song); Buyi's folk song (Good Red Tone) in Huishui County; Lusheng } \\
\text { music in Danzhai County (Dong's Lusheng, Miao's Lusheng); Buyi’s Leyou in Zhenfeng, Xingyi and Zhenning; Grand Song of } \\
\text { Dong Minority (Extended site) in Congjiang and Rongjiang County; Polyphonic folk song in Taijiang and Jianhe County } \\
\text { (Extended site) }\end{array}$ & Second \\
\hline & $\begin{array}{l}\text { Dong's Pipa Song in Congjiang County (Extended site); Miao's folk songs in Jianhe County (Miao's Flying Song) (Extended } \\
\text { site); Yi's folk song in Pan County (Extended site) }\end{array}$ & Third \\
\hline \multirow{3}{*}{$\begin{array}{l}\text { Traditional } \\
\text { Dance }\end{array}$} & $\begin{array}{l}\text { Miao's Lusheng Dance in Danzhai, Guiding and Nayong County (Pheasant Dance; Drum Dragon Drum Tiger; Rolling Hill } \\
\text { Beads); Wooden drum dance in Taijiang County (Anti-handling) }\end{array}$ & First \\
\hline & $\begin{array}{l}\text { Maonan's Monkey and Drum Dance in Pingtang County; Yao's Monkey and Drum Dance in Libo County; Yi's Bell Dance in } \\
\text { Hezhang County; Lion dance in Xingyi City; Miao's Lusheng Dance in Leishan, Rongjiang, Shuicheng, and Guanling Buyi and } \\
\text { Miao Autonomous County }\end{array}$ & Second \\
\hline & Miao's Lusheng Dance in Puan County (Extended site) ; Buyi’s Rotating Dance in Ceheng County & Forth \\
\hline \multirow{4}{*}{$\begin{array}{l}\text { Traditional } \\
\text { Drama }\end{array}$} & Dong's opera in Liping County; Buyi’s opera in Ceheng County; Yi’s Cuotaiji in Weining Yi Hui and Miao Sutonomous County & First \\
\hline & $\begin{array}{l}\text { Qianju opera of Qianju Opera Troupe; Huadeng opera in Dushan County (Extended site); Nuo opera in Daozheng Gelao } \\
\text { Nationality Autonomous County (Extended site) }\end{array}$ & Second \\
\hline & Huadeng opera of Guizhou Huadeng Opera Troupe; Nuo opera in Libo County (Buyi’s nuo opera) & Third \\
\hline & Nuo opera in Jinsha County (Altar) (Extended site) & Forth \\
\hline Quyi & Buyi's Eight Notes Sitting Singing in Xingyi City & First \\
\hline
\end{tabular}

\section{The CURRENT SituATION OF GUIZHOU ETHNIC SONGS,} DANCES AND OPERAS DEVELOPMENT UNDER THE GUIDANCE OF CULTURAL INDUSTRY DEVELOPMENT

\section{A. Policy and Effectiveness}

In 2006, Guizhou Provincial Intangible Cultural Heritage Protection Center was formally established to promote the comprehensive development of intangible cultural heritage protection. In May 2012, "Regulations on the Protection of Intangible Cultural Heritage in Guizhou Province" was officially implemented. In 2014, "Guizhou Intangible Cultural Heritage Protection and Development Plan (2014-2020)" was announced. In 2009, Grand Song of Dong Minority was listed in the World Intangible Cultural Heritage List. In 2014, the "Colorful Guizhou Grand Song of Dong Minority Inheritance and Protection Action Plan" was officially launched, and the government invested about 10 million yuan of special funds every year to carry out the protection and inheritance work of the Grand Song. In January 2015, the Dong minority's musical poem "Singing on the Moon" premiered at the National Grand Theater, which opened a national tour and achieved good results. In 2016, the world's first field-recorded Grand Song of Dong Minority theme album "Talent Dong Listening" came out.

In 2005, the annual "Colorful Guizhou" singing contest was launched. In 2018, this contest attracted more than 100,000 people from all over the province. In 2006, the large-scale folk song and dance poem "Colorful Guizhou Style" was grandly launched. With 800 actors from 17 indigenous nationalities in Guizhou Province, it has been elaborately produced in four versions over 13 years. Its commercial performances have spread over more than 40 countries around the world, and it has been listed in the list of "National Cultural Tourism Key Project". In 2007, Guizhou launched an annual "Colorful Guizhou" dance contest to promote the dance culture industry centered on ethnic dance. In recent years, with intangible cultural resources as the material and singing and dancing opera as the main form of performance, large-scale tourism performances have been constantly innovating, promoting the development of national s singing and dancing art. "Splendid Danzhai", "Xijiang Grand Ceremony", "Fantastic Fanjing Mountain", "Butterfly Mother" and other tourism performances have become important projects to show the singing and dancing art of Guizhou.

\section{B. Existing Problems}

People are not Proud of Traditional Culture.

With the development of society and economy, children of ethnic minorities generally receive modern cultural education. Some rituals, customs and beliefs of their own ethnic groups are resisted because of changes in their ideology and concepts, which makes them less enthusiastic about their traditional culture. For example, the fundamental reason for all ethnic groups living in Dejiang to believe in Nuotang opera is that they believe that Nuotang opera can drive away ghosts and drive away epidemics, eliminate disasters and pray for blessings [1]. But now young people no longer believe in the magic power of eliminating diseases and protecting peace. When they no longer believe in it, they are not willing to spend a lot of time and energy to learn and inherit. For another example, the Grand Song of Dong Minority originally had multiple social functions, but with the advent of the Internet era whether it is the collective duet of men and women in Drum Tower, or the duet of men and women in Yuetang, it seems out of date for young people, and is becoming more and more "rustic". The love way of singing Grand Song is gradually replaced by the way of telephone, QQ chat, SMS and so on [2]. The lack of strong national cultural pride has led to the gradual disintegration of the original folk spontaneous inheritance system, and the unique ethnic customs have gradually faded.

The follow-up power of inheritance is insufficient. 
Now most of the inheritors of intangible cultural heritage are old. While most of the time, students need to study in school and young people need to go out to make a living, they can't afford the time cost for the inheritance of song and dance. For example, the Dong nationality is a nation without written language. Singing and chanting is an extremely frequent and important daily behavior of the Dong people. It is the main way of transmitting and continuing ethnic information to record things with songs [3]. The Grand Song of Dong Minority can only be learned on the basis of mastering the Dong language, and it takes time and effort to learn it. Now, the young Dong people have no time to learn the Dong language and Grand Song. With the passing of the old Dong people, there are fewer and fewer people who can sing the Grand song.

The ability of innovative transformation of national culture is poor.

Intangible cultural heritage stems from people's production methods and lifestyles. These colorful ethnic songs, dances and operas were formed and developed in the traditional Chinese farming society. With the transformation of production methods in modern society, the soil for the survival of intangible cultural heritage is becoming increasingly barren. Whether it can continuously absorb new artistic nutrition and create new works on the traditional basis has become the key to its survival. Even the well-known ethnic operas, such as Dong opera and Buyi opera, still lack the innovation ability of sustainable development [4]. For many ethnic minority cultures facing extinction, the subjective consciousness of many folk entertainers has not yet fully awakened, and academic choreographers do not possess ethnic minority culture, life, or spiritual memory [5]. In the inheritance of ethnic songs, dances and operas, it lacks the inheritance and innovation in the native soil, and cannot be combined with modern popular elements to create more popular cultural products.

\section{Cultural enterprises are not very competitive.}

In 2005, Guizhou launched the provincial cultural brand "Colorful Guizhou". In more than ten years, with the "Colorful Guizhou" brand as the leader, the leading force in the fields of performance training, cultural creativity, cultural tourism, etc. has been highlighted, and the core competitiveness of the cultural industry has been continuously improved. But overall, the number of singing and dancing performing arts cultural enterprises in Guizhou Province is small and started late. Colorful Guizhou Culture and Art Co., Ltd. is the only cultural enterprise awarded by the Ministry of Culture as the "National Cultural Industry Demonstration Base". Other large-scale singing, dancing, and performing arts cultural enterprises were established late with small influence. In addition, at present, although the live performances and theater performances with ethnic cultural resources as the core are gradually expanding, the product types are single and mainly exported to tourists. Other types of multicultural products such as Quyi, film, and television need to be further enriched.

\section{SUGGeSTIONS}

Hu Huilin (2017) elaborated the essence of cultural industry in the article "On the Essence of Cultural Industries: Rebuilding the Cognitive Dimension of Cultural Industry": cultural industry is the form of cultural productivity in social development [6]. Cultural productivity is determined by three factors: the workers who produce spiritual products in cultural production, the materials of labor and the objects of labor in cultural production [7]. Based on the three elements of cultural productivity, this paper puts forward some suggestions on the inheritance of ethnic songs, dances and operas, hoping to promote the effective inheritance from the perspective of cultural industry development.

\section{A. From the Perspective of Laborer}

The laborer in the cultural productivity refers to the laborer with certain knowledge and ability, which needs to be acquired through long-term study and training. Human is the most fundamental cultural productivity, and human resources are the core of cultural production. The lack of inheritors is not only a problem in the inheritance of intangible cultural heritage in Guizhou, but also a common problem in the whole country and even in the world.

From the perspective of industry, the most basic assumption in Economics is that people's behavior is driven by self-interest motivation. They seek benefits and avoid disadvantages, and pursue the maximization of their own interests. In terms of market value, intangible cultural heritage does not make the workers (inheritors of intangible cultural heritage) obtain satisfactory income in economic activities, so it can't really stimulate the initiative of the people to inherit intangible cultural heritage. By investigating 186 samples from 11 ethnic groups including the Miao, Dong, Tujia, Yi, Gelao, $96.2 \%$ of them are proud of their intangible cultural heritage resources, but this "pride" is contrary to daily behavior. For example, they do not like to wear ethnic costumes, do not speak ethnic languages, and do not want to participate in ethnic sacrificial activities. The reason is that the practicability of national culture is not strong. Only when intangible cultural heritage can bring the compensation function of money in addition to the soothing function of spirit, can it really activate.

The growth of human resources requires the intervention of the government in addition to the regulatory role of the market economy. The knowledge and skills of laborers in cultural productivity need to be acquired through long-term learning and training, so the inheritors of intangible cultural heritage should have enough learning time. At present, the "Intangible Cultural Heritage Classroom" launched in various places has introduced the education into the campus, promoting the learning and understanding of the intangible cultural heritage among young children. However, the skills of ethnic songs, dances and operas are far from enough to be learned by only one class a week. Therefore, in talent education, it is suggested to strengthen the directional training of talents. For example, some ethnic songs, dances and operas skills are regarded as artistic specialties, and professional art examinations or special skills are set up to promote teenagers' learning and strengthen systematic training. In the aspect of higher education, some scholars put forward the ways of setting up intangible cultural heritage curriculum system, setting up independent colleges and universities, etc. to train artistic applied talents. The ethnic songs, dances and operas are used as performing arts. Although the nature of intangible cultural heritage activities has changed 
a lot, from functional to performing, from mass singers to professional singers, this is consistent with the overall trend of ethnic music [8].

Cultural enterprises also play the role of labor in the productive forces. Improving the competitiveness of cultural enterprises, promoting the innovation, dissemination and display of ethnic songs, dances and operas, and enriching cultural business activities are important means to promote the inheritance of intangible cultural heritage. Now, Guizhou has launched a number of excellent stage performance plays. In the future, we should further promote the integration of culture and tourism, strengthen the strength of culture and related industries, and make full use of Guizhou's rich ethnic cultural resources in a broader field and deeper level. We will encourage innovation in the presentation of ethnic songs, dances and operas, and promote the promotion of tourism through culture.

\section{B. From the Perspective of Labor Materials}

Labor materials for cultural production are the labor tools and techniques used in the cultural production process. Science and technology is the most important form of cultural productivity in the development of the cultural industry. Nowadays, the development of $5 \mathrm{~g}$, AR, VR, holographic projection, modern media and other technologies provides unprecedented opportunities for the presentation of song, dances and operas. Refining cultural and artistic elements of intangible cultural heritage and injecting them into cultural products such as film, television, animation, games, and creative design by means of science and technology, and lengthening the cultural industry chain are effective measures to promote non-genetic inheritance. In view of the inheritance of intangible cultural heritage, UNESCO emphasizes in the convention that to adapt to the surrounding environment and get innovation in the interaction with nature and history, it is a living inheritance that is expressed in a popular language [4]. Nowadays, science and technology has become an important language. The display and dissemination of intangible cultural heritage by means of science and technology will be more in line with the aesthetic "popular expression" of the times.

\section{From the Perspective of Labor Object}

The object of labor in cultural production refers to what is processed in the production process of spiritual products, including the spiritual content produced by human beings, the material materials obtained directly from the nature and the raw materials created through labor processing. The proper processing of traditional culture and art is the key to the success of industrialization. The Shanghai Fine Arts Film Studio, established in 1957, pushed Chinese animation to the world's peak in the 1980s. A series of cartoons, such as "Little Tadpole Looking for Mother", "Havoc in Heaven", "Nezha Noisy Sea", fully absorbed the elements of traditional Chinese culture in the aspects of story plot, image design, body language, clothing color, setting music and so on, and achieved the innovation of the combination of nationality and cosmopolitanism. The ethnic songs, dances and operas in Guizhou are mostly related to festivals and sacrifices. The industrialization development needs to strip out suitable elements, rather than copy them all. In the short term, the more effective way is to combine traditional art forms such as opera with modern popular elements to attract the public. This requires talents with keen intuition in this field, and a lot of attempts [9]. In 2011, Shang Wenjie's song "Love warrior War" used a lot of elements of "Grand Song of Dong Minority" which is very characteristic of Chinese minority music, and was well received. Traditional songs, dances and operas combined with modern musical elements such as piano and electronics can create popular cultural products as a way. Therefore, the industrialization process of intangible cultural heritage resources is an artistic innovation process and a process of constantly accumulating new cultural wealth.

\section{CONCLUSION}

How the intangible cultural heritage formed in the traditional farming society has more connections with people's production and life in modern society requires us to uphold an innovative attitude, so that traditional protection and artistic innovation can truly move side by side. The inheritance of ethnic songs, dances and operas needs real artists to extract their most essential and orthodox genes, and provide cultural services for people's spiritual life in the way of stage, theater, film and television, so that more people can obtain spiritual comfort and satisfaction in cultural consumption. Ethnic songs, dances, and operas carry the life concepts, aesthetic tastes, and social values of people of their own nationality. In the process of industrialization, they should not be changed easily for the sake of industrialization, but should be innovated in system inheritance.

\section{REFERENCES}

[1] Zh. Y. Wang. "Research on the Social Functions of Nuo Opera in Dejiang," Symposium on Nuo culture in Fanjing Mountain, China, China Drama Press, Beijing, 2003. (In Chinese).

[2] X. R. Li, T. B. Wu, and R. L. Dai "On the Problems of Protecting Grand Song of Dong Minority and the Countermeasures," Journal of Zuny Normal University, Vol. 19, No. 6, pp. 133-136, 2017. (In Chinese).

[3] D. Han. "The Problems Existing in the Protection of Grand Song of Dong Minority in the New Period and the Solutions," Journal of Musical Composition, No. 12, pp. 136-138, 2018. (In Chinese)

[4] W. F. Liu. "Thoughts on Several Issues of Inheritance and Protection of Traditional Drama," Cultural Heritage, No. 6, pp. 51-59, 2017. (In Chinese).

[5] F. Zhang, L. L. Ma, and N. J. Geri. "Thoughts on Contemporary Ethnic Folk Dance Creation," Guizhou Ethnic Studies, Vol. 40, No. 10, pp. 128-131, 2019. (In Chinese).

[6] H. L. Hu. "On the Essence of Cultural Industries: Rebuilding the Cognitive Dimension of Cultural Industry," Journal of Shandong University (Philosophy and Social Sciences), No. 3, pp. 01-15, 2017. (In Chinese).

[7] Ch. Wang, D. Zhang. Cultural Resources Studies, Nanjing University Press, Nanjign, 2014

[8] X.Z. Shichun. "Research on Inheritance Channels of Buyi Folk Songs from the Perspective of Cultural Identity," Guizhou Social Sciences, No. 12, pp. 87-92, 2019. (In Chinese).

[9] Y. P. Jin. "Scene Theory and Inheritance and Innovation of Cultural and Artistic Heritage: A Conversation between Jin Yuanpu and Laurence,' Journal of Beijing Union University (Humanities and Social Sciences) Vol. 18, No. 1, pp. 25-29, 2020. (In Chinese). 